\title{
There's no place like home: Integrating pulmonary rehabilitation into the home setting
}

\author{
Madalina Macrea1,2, Richard ZuWallack ${ }^{3,4}$, Linda Nici5 \\ 1 University of Virginia, Charlottesville, VA \\ 2 Salem VA Medical Center, Salem, VA \\ 3 St. Francis Hospital and Medical Center, Hartford, CT \\ 4 University of Connecticut, Hartford, CT \\ 5 The Warren Alpert Medical School of Brown University, Pulmonary \& Critical Care Section, Providence, \\ RI, USA
}

\begin{abstract}
Traditional, outpatient pulmonary rehabilitation provided to stable chronic obstructive pulmonary disease (COPD) patients leads to significant improvements in dyspnea, exercise capacity and health related quality of life. Also, when started during or shortly after a hospitalization for a COPD exacerbation, pulmonary rehabilitation improves these patient-centered outcomes and arguably reduces subsequent health care utilization and mortality. Despite these benefits, the uptake of traditional pulmonary rehabilitation remains disappointingly poor. Homebased pulmonary rehabilitation, a safe and effective alternative to traditional, center-based programs, can broaden access. While proven improvements in dyspnea, exercise capacity and health status justify implementation of home-based pulmonary rehabilitation, it would be helpful to know whether it can also decrease health care utilization and be cost-effective.
\end{abstract}

Corresponding author: Madalina Macrea, Salem VA Medical Center, 1970 Roanoke Blvd, Salem, VA 24153, USA. E-mail: Madalina.Macrea@va.gov

Key words: Home pulmonary rehabilitation; chronic obstructive pulmonary disease; integrated medical care.

Authors' contribution: MM, manuscript writing, literature review; RZW, LN, manuscript concept and writing, literature review.

Conflict of interest: The authors declare no conflict of interest.

Received for publication: 1 June 2017

Accepted for publication: 13 June 2017

(C) Copyright M. Macrea et al., 2017

Tipografia PI-ME Editrice, Italy

Monaldi Archives for Chest Disease 2017; 87:859

doi: 10.4081/monaldi.2017.859

This article is distributed under the terms of the Creative Commons Attribution Noncommercial License (by-nc 4.0) which permits any noncommercial use, distribution, and reproduction in any medium, provided the original author(s) and source are credited.

\section{Introduction}

The optimal treatment of patients with chronic obstructive pulmonary disease (COPD) must blend pharmacologic and non-pharmacologic therapies. Included in the latter is pulmonary rehabilitation, which has high-quality evidence documenting its benefit across multiple outcomes of importance to the patient, including dyspnea, exercise tolerance and health status [1]. A systematic review suggests it also leads to a reduction in health care utilization, especially in the post-hospitalization period of a COPD exacerbation [2], although one large randomized controlled trial of pulmonary rehabilitation notably failed to demonstrate a positive effect in this area [3].

Despite these benefits, pulmonary rehabilitation has been grossly underutilized [4], probably for multiple reasons, including underrecognition of its importance by healthcare professionals and patients, unwillingness of the patient to attend sessions, unavailability of programs in certain geographic areas, and insufficient third-party reimbursement [5]. After hospitalization for an exacerbation, when the need for pulmonary rehabilitation is arguably greatest, attendance at centers is especially problematic [6]. Offering pulmonary rehabilitation in the home or community setting might increase referrals and patient participation, thereby reducing the effect of under-utilization. Adding to this argument, randomized trials comparing center-based to home-based interventions show equivalence across several patientcentered outcome areas, including dyspnea-relief and improvements in health status and exercise capacity [7-8]. The effect of home-based pulmonary rehabilitation in the post-exacerbation period for COPD has not been adequately tested. This discussion amplifies the rationale for research testing of the feasibility, effectiveness, safety, and costs of delivering pulmonary rehabilitation in the home setting of discharged COPD patients.

\section{The burden of COPD}

COPD, including its systemic effects and common comorbidities, imposes a substantial symptomatic and functional burden on the individual patient, including disabling symptoms such as dyspnea, cough and fatigue; exercise intolerance and physical inactivity; impaired health and functional status; and psychological dysfunction including cognitive impairment, anxiety and depression. Adding to these patient-centered negative outcomes, this preventable disease reached the ignominious level as the third leading cause of death world-wide 
and its direct costs have skyrocketed, reaching $\$ 32$ billion in the United States and $€ 38.6$ billion in the European Union [9].

Exacerbations add further to the burden of COPD, resulting in severe and relatively prolonged deterioration in symptoms, functional and health status [10-14], increased mortality risk [15-16], and increased subsequent health care utilization. In an analysis of Medicare claims data in the United States, including COPD patients, approximately onefifth of Medicare beneficiaries were re-hospitalized within 30 days and $34 \%$ were re-hospitalized within 90 days of the original discharge date [17]. There are undoubtedly many reasons for this increased health care utilization, including the underlying severity of the respiratory disease and co-morbidities, the fact that exacerbated and vulnerable COPD patients are discharged home early on in the course of the exacerbation [18], temporal clustering of exacerbations, inadequate self management skills, insufficient infrastructure support to the transition from hospital to home [19], and often inadequate and inefficient resources to manage patients after discharge [20]. These deficiencies are not easily corrected.

\section{Pulmonary rehabilitation, collaborative self-management and integrated care}

The 2013 Statement on Pulmonary Rehabilitation from the American Thoracic Society and European Respiratory Society defines this intervention as "... a comprehensive intervention based on a thorough $p a-$ tient assessment followed by patient-tailored therapies, which include, but are not limited to, exercise training, education, and behavior change, designed to improve the physical and psychological condition of people with chronic respiratory disease and to promote the long-term adherence of health-enhancing behaviors" [1]. Exercise training along with education and behavior change therapies, aimed at improving self-efficacy and provided by an interdisciplinary team, are central features of pulmonary rehabilitation.

Despite having no direct effect on lung function in COPD, pulmonary rehabilitation typically leads to clinically-meaningful improvements in exercise tolerance, dyspnea, functional and health status [21], although these beneficial effects may decrease in the months-years following participation in the program [22]. One approach to enhancing and sustaining the benefits realized from pulmonary rehabilitation is a focus on behavior change, which is a central feature of collaborative self management education. Self-management in this context is patient-centered education aimed at teaching skills and enforcing behaviors that promote health [23]; these include COPD education, medication management (adherence and inhaler technique), smoking cessation, action plans, promoting exercise and physical activity, proper nutrition, and coping mechanisms [24].

Integrating the management of the COPD patient over the long trajectory of the disease is required for optimal outcomes [25]. In addition to pulmonary rehabilitation and self management, this includes coordination of care among health care providers and settings. This is especially important in the peri-hospitalization period of the COPD exacerbation, which is characterized by high symptom burden, worsening functional status, increased care utilization, and high morality risk.

\section{Pulmonary rehabilitation settings}

Pulmonary rehabilitation as a patient-centered intervention administered by an interdisciplinary team can be provided in either inpatient or outpatient venues. The latter include outpatient, center-based; outpatient, community-based; and outpatient home-based settings. A survey of pulmonary rehabilitation organizational content involving 430 centers from 40 counties demonstrated that about $90 \%$ of programs offered outpatient services, either alone or along with inpatient services [26]. Center- or hospital-based programs are most common. The reasons for this probably reflect availability of personnel and space resources as well as third-party reimbursement payments.

Practically speaking, the severity of the underlying illness (including its systemic effects and comorbid conditions), third-part reimbursement, and availability of programs in the geographic area usually dictate where the intervention is given. It is important to note that regardless of the setting, the best outcomes are largely driven by the skill and commitment of the staff that deliver the program [27].

\section{The rationale for pulmonary rehabilitation in the home}

Center (hospital)-based outpatient pulmonary rehabilitation has the professional and physical resources to effectively provide a comprehensive intervention by an interdisciplinary team. Home-based pulmonary rehabilitation does not come close to having these resources, so other factors must provide its raison d'être. An editorial by Mike Morgan [27] summarizes of this rationale:

- Only about $15 \%$ of those COPD patients with significant disability are ever referred to pulmonary rehabilitation, often owing to lack of local capacity.

- Only about $2 / 3$ of patients referred to traditional centers show up to initiate treatment.

- Only about $70 \%$ beginning rehabilitation complete the program. Dropouts from center based programs are probably greater than those from home-based programs.

Home based programs would certainly increase capacity and may increase uptake and completion of pulmonary rehabilitation, and its oneon-one approach may better promote individualization of care. Furthermore, although little evidence-based data are available, maintenance of gains may last longer when the treatment in given in the familiar, home setting [28]. Whether these mostly-theoretical benefits will be actualized in real-life settings remains to be determined. In some health settings, such as in the United States, the case for potential benefits is moot since reimbursement for home visits as part of pulmonary rehabilitation is not provided.

\section{Home-based pulmonary rehabilitation}

Home-based pulmonary rehabilitation is perhaps the least common setting for this intervention, as less than 5\% of programs offer this option [26]. There is no universal agreement of just what comprises home-based pulmonary rehabilitation, other than that a substantial portion (but not necessarily all) of the intervention is provided in the home setting. Table 1 lists various conceptions of home-based pulmonary rehabilitation, provided for stable COPD patients or in the periexacerbation period $[3,7,8,28,29-38]$. It is important to note that the pulmonary rehabilitation intervention in these studies is exceedingly heterogeneous, underscoring the lack of consensus of what this intervention encompasses.

Two relatively large randomized, controlled trials of home-based versus outpatient, hospital-based pulmonary rehabilitation for clinically stable COPD patients serve to illustrate current concepts of the 
Table 1. Home based pulmonary rehabilitation duration, sessions and components.

\begin{tabular}{|c|c|c|c|c|}
\hline $\begin{array}{l}\text { Author, } \\
\text { year }\end{array}$ & Sessions, duration & Education component & Exercise component & Comments \\
\hline \multicolumn{5}{|c|}{ For clinically-stable COPD patient } \\
\hline $\begin{array}{l}\text { Strijbos, } \\
1996[30]\end{array}$ & $\begin{array}{l}\text { Twenty-four sessions, } \\
12 \text { weeks }\end{array}$ & $\begin{array}{l}\text { Information on inhaler use } \\
\text { and when to seek medical } \\
\text { help; location of education } \\
\text { not specified }\end{array}$ & $\begin{array}{l}\text { Supervised by physiotherapist and nurse, } \\
\text { individualized, breathing and relaxation, } \\
\text { walking, stair climbing, stationary bicycle }\end{array}$ & $\begin{array}{l}\text { Stable COPD, hospitalized } \\
\text { for } 2 \text { days first }\end{array}$ \\
\hline $\begin{array}{l}\text { Wedzicha, } \\
1998[29]\end{array}$ & $\begin{array}{l}\text { Sixteen sessions, } \\
8 \text { weeks }\end{array}$ & $\begin{array}{l}\text { Sessions of 45-min duration, } \\
\text { general education, relaxation } \\
\text { techniques, inhaler, } \\
\text { nebulizer and oxygen use, } \\
\text { nutrition, smoking cessation } \\
\text { and psychological problems }\end{array}$ & $\begin{array}{l}\text { Unloaded upper and lower limb training, } \\
\text { centering on walking, target } 1 \mathrm{~h} \text { daily }\end{array}$ & $\begin{array}{l}\text { Home-based PR provided to } \\
\text { home-bound COPD patients } \\
\text { with severe dyspnea, } \\
\text { physiotherapist supervision }\end{array}$ \\
\hline $\begin{array}{l}\text { Hernandez, } \\
2000[8]\end{array}$ & $\begin{array}{l}\text { Six sessions per week, } 12 \\
\text { weeks; visits to center every } \\
2 \text { weeks for supervision }\end{array}$ & Not specified & $\begin{array}{l}\text { Predominately lower extremity training } \\
\text { centering on outdoor walking, individualized, } \\
\text { initial goal } 70 \% \text { of maximum }\end{array}$ & Stable COPD \\
\hline $\begin{array}{l}\text { Boxall, } \\
2005[4]\end{array}$ & $\begin{array}{l}\text { Once daily exercise, } \\
12 \text { weeks, average } 11 \text { home } \\
\text { visits; weekly physiotherapy } \\
\text { visits for the first } 6 \text { weeks, } \\
\text { then fortnightly }\end{array}$ & $\begin{array}{l}\text { Provided by physiotherapy, } \\
\text { nursing, and occupational } \\
\text { therapy in the home; typically } \\
6 \text { sessions of general } \\
\text { education, medication, } \\
\text { energy conservation }\end{array}$ & $\begin{array}{l}\text { Graduated walking and arm exercises, } \\
\text { each beginning at low intensity } \\
\text { and duration and increased according } \\
\text { to protocol }\end{array}$ & $\begin{array}{l}\text { Stable COPD referred by } \\
\text { hospital-based physicians } \\
\text { or physiotherapists }\end{array}$ \\
\hline $\begin{array}{l}\text { Resqueti, } \\
2007[35]\end{array}$ & $\begin{array}{l}\text { Six center-based sessions, } \\
\text { approximately } 35 \text { home } \\
\text { sessions, } 9 \text { weeks total }\end{array}$ & $\begin{array}{l}\text { Center-based education } \\
\text { before initiating home-based } \\
\text { exercise, education centers } \\
\text { on exercise techniques }\end{array}$ & $\begin{array}{l}\text { Exercise initiated in centers, followed } \\
\text { by } 7 \text { weeks in home: leg and arm } \\
\text { exercises, inspiratory muscle training, } \\
1.5 \text { hours per session, } 5 \text { days per week }\end{array}$ & $\begin{array}{l}\text { Severe to very severe COPD. } \\
\text { Initial center-based education } \\
\text { and exercise followed by home } \\
\text { exercise }\end{array}$ \\
\hline $\begin{array}{l}\text { Maltais, } \\
2008 \text { [7] }\end{array}$ & $\begin{array}{l}\text { Four center-based } \\
\text { educational sessions, } \\
24 \text { home-based exercise } \\
\text { sessions, } 12 \text { weeks total }\end{array}$ & $\begin{array}{l}8 \text { sessions given in center } \\
\text { over initial } 4 \text { weeks, } \\
\text { centering on self- } \\
\text { management }\end{array}$ & $\begin{array}{l}\text { Stationary cycle aerobic training, } 3 \text { times } \\
\text { weekly for } 8 \text { weeks, target intensity } \\
\text { was } 60 \% \text { of maximal capacity, target } \\
\text { duration } 40 \text { min per session, plus } \\
\text { strengthening exercises }\end{array}$ & $\begin{array}{l}\text { Stable COPD } \\
\text { Exercise specialist initiated } \\
\text { exercise in the home, weekly } \\
\text { telephone calls }\end{array}$ \\
\hline $\begin{array}{l}\text { Fernandez, } \\
2009[6]\end{array}$ & $\begin{array}{l}\text { Two 1-h sessions in center, } \\
5 \text { home sessions per week, } \\
12 \text { months }\end{array}$ & $\begin{array}{l}\text { Education and exercise } \\
\text { education at } 2 \text { initial center- } \\
\text { based sessions, general } \\
\text { education plus training } \\
\text { on exercise techniques }\end{array}$ & $\begin{array}{l}\text { Inspiratory muscle training, isotonic } \\
\text { upper and lower limb exercises, walking } \\
\text { exercises at } 90 \% \text { of } 6 \text {-min walking speed; } \\
\text { Target exercise: } 1 \text { hour per session, } \\
5 \text { days per week }\end{array}$ & $\begin{array}{l}\text { Very severe COPD on home } \\
\text { oxygen } \\
\text { Twice monthly home visits by } \\
\text { physiotherapist for } 2 \text { months, } \\
\text { followed by monthly home visits }\end{array}$ \\
\hline $\begin{array}{l}\text { Holland, } \\
2017[8]\end{array}$ & $\begin{array}{l}\text { One home visit and } 7 \text { once- } \\
\text { weekly telephone calls, } \\
8 \text { weeks total }\end{array}$ & $\begin{array}{l}\text { Patients given written } \\
\text { self-management education } \\
\text { pamphlet }\end{array}$ & $\begin{array}{l}30 \text { minutes of aerobic training per } \\
\text { session, usually walking exercise, } \\
\text { pedometer feedback, sit-to-stand } \\
\text { exercises, light weight resistance training }\end{array}$ & $\begin{array}{l}\text { Stable COPD } \\
\text { Aimed at utilizing minimal } \\
\text { resources; } 1 \text { home visit } \\
\text { by physiotherapist, weekly } \\
\text { telephone calls }\end{array}$ \\
\hline \multicolumn{5}{|c|}{ In the peri-exacerbation period } \\
\hline $\begin{array}{l}\text { Behnke, } \\
2000[2]\end{array}$ & $\begin{array}{l}\text { Ten-day walking training } \\
\text { program in the hospital, } \\
\text { followed by } 3 \text { times a day } \\
\text { home walking for } 6 \text { months }\end{array}$ & Not specified & $\begin{array}{l}\text { Walking at } 125 \% \text { of best } 6 \text {-minute treadmill } \\
\text { walking distance, breathing exercises }\end{array}$ & $\begin{array}{l}\text { COPD, following hospitalization } \\
\text { for exacerbation; walking training } \\
\text { started in hospital }\end{array}$ \\
\hline $\begin{array}{l}\text { Revitt, } \\
2013[28]\end{array}$ & $\begin{array}{l}\text { Center-based, } 4 \text { weeks; } \\
\text { home-based } 3 \text { weeks }\end{array}$ & $\begin{array}{l}\text { Provided in the rehabilitation } \\
\text { center over the first } 4 \\
\text { weeks, } 1 \text { h-session }\end{array}$ & $\begin{array}{l}\text { Home component: Daily walking } \\
\left(85 \% \text { of peak } \mathrm{VO}_{2}\right) \text { and } 3 \text {-times } \\
\text { weekly resistance training }\end{array}$ & $\begin{array}{l}\text { COPD, following hospitalization } \\
\text { for exacerbation } \\
\text { Mixed, center-based ( } 4 \text { weeks) and } \\
\text { home-based ( } 3 \text { weeks) structured, } \\
\text { unsupervised rehabilitation }\end{array}$ \\
\hline $\begin{array}{l}\text { Greening, } \\
2014[3]\end{array}$ & $\begin{array}{l}\text { Variable, in hospital } \\
\text { intervention followed by at- } \\
\text { home training, } 6 \text { weeks total }\end{array}$ & $\begin{array}{l}\text { Provided in the hospital } \\
\text { setting and during } \\
\text { subsequent telephone calls }\end{array}$ & $\begin{array}{l}\text { Home component: daily walking, } \\
\text { neuromuscular electrical stimulation } \\
\text { (some patients), supported by telephone } \\
\text { calls and motivational interviewing }\end{array}$ & $\begin{array}{l}\text { Early rehabilitation (within } 48 \mathrm{~h} \\
\text { of admission) initiated in the } \\
\text { hospital, continued at home }\end{array}$ \\
\hline $\begin{array}{l}\text { Ko, } 2016 \\
{[38]}\end{array}$ & Twelve months total & $\begin{array}{l}\text { 21-hour sessions by a nurse, } \\
\text { including general education, } \\
\text { self-management, coping } \\
\text { skills }\end{array}$ & $\begin{array}{l}\text { Individualized physical training program, } \\
\text { given at a center or home, details } \\
\text { not specified }\end{array}$ & $\begin{array}{l}\text { COPD, following hospitalization } \\
\text { for exacerbation } \\
\text { Mixed, center-based and home- } \\
\text { based pulmonary rehabilitation; } \\
\text { telephone calls every } 3 \text { months }\end{array}$ \\
\hline
\end{tabular}


home-based intervention. In a study by Maltais and colleagues conducted in Canada [7], the home-based program consisted of: i) A 4week education program (focusing on self-management) given in the outpatient, hospital setting; ii) Aerobic and strength exercises 3 times weekly for 8 weeks in the home; and iii) An unstructured maintenance program. The home exercise centered on training using portable cycle ergometers (supplied to the patients, but taken away after study completion), initiated in the home by an exercise specialist, with a target intensity of $60 \%$ maximal work rate, a duration of $40 \mathrm{~min}$, and a frequency of three times weekly, and follow-up with weekly telephone calls. In contrast, in a study by Holland and colleagues conducted in Australia [8], the home-based intervention included one home visit by a physiotherapist to establish exercise goals and supervise the first exercise session, 30-min of twice-weekly walking exercise supported by pedometer feedback, light resistance training, and low intensity calisthenics (such as sit-to-stand exercises). Once-weekly telephone calls from the physiotherapist, using motivational interviewing techniques were given; and selected self-management education and goal setting were incorporated into these weekly discussions. This program lasted 8 weeks.

A review of the home based pulmonary rehabilitation duration, sessions and components is presented in Table 1.

\section{Outcomes from home-based pulmonary rehabilitation}

The marked variability in the application of home-based pulmonary rehabilitation (stable COPD versus peri-exacerbation); in educational and exercise components (supervised, unsupervised, duration, intensity, etc.); hybrid natures of some programs (inpatient or center-based followed by home-based interventions); and experimental design (intervention versus usual care or versus center-based) make universal efficacy conclusions virtually impossible. One meta-analysis of 18 randomized controlled studies involving 733 patients, from 1991 to 2012 [39], showed positive results (compared to non-intervention control groups), in dyspnea, health-related quality of life, and exercise capacity. No significant changes were seen in maximal exercise workload, hospital admission, cost of care, or mortality. Notably, adverse events were rare and not different between home-based or centerbased programs.

It is important to note that the studies in the above-mentioned metaanalysis compared home based treatments with usual care. Two relatively-recent trials of stable COPD patients compared home-based rehabilitation to traditional, center (hospital) - based rehabilitation [8], [24], which is now considered a standard of care [1]. The specifics of the interventions were described previously. Both trials showed equivalent outcomes in the two treatment settings in patient-centered outcomes of dyspnea and exercise tolerance. Health care utilization was not studied in either trial.

\section{Future directions}

Based on the preceding discussion, the following areas deserve further development:

i) A universally-agreed-upon model of what constitutes home-based pulmonary rehabilitation. Using the current definition [1] as the basis; this would include patient selection criteria (who would best be served?), specifics of both the exercise and self-management components, timing and duration, and whether it should be construed as a stand-alone program or as a bridge to center-based programs. This initiative would require analysis of evidence-based data and considerable expert opinion.

ii) Randomized, controlled trials evaluating home-based pulmonary rehabilitation in the peri-exacerbation period, including health care utilization as a prominent outcome; the first step would be to compare it with usual care, and then (if successful) with traditional pulmonary rehabilitation.

iii) An exploration of the potentially longer duration of benefits that may be realized with a home-based intervention as compared to traditional programs where benefits often decline at 1-2 years.

\section{References}

1. Spruit MA, Singh SJ, Garvey C, et al. An official american thoracic society/european respiratory society statement: Key concepts and advances in pulmonary rehabilitation. Am J Resp Crit Care Med 2013;188:e13-64.

2. Puhan MA, Gimeno-Santos E, Scharplatz M, et al. Pulmonary rehabilitation following exacerbations of chronic obstructive pulmonary disease. Cochrane Database Syst Rev 2011:CD005305.

3. Greening NJ, Williams JE, Hussain SF, et al. An early rehabilitation intervention to enhance recovery during hospital admission for an exacerbation of chronic respiratory disease: Randomised controlled trial. BMJ 2014;349:g4315.

4. Rochester CL, Vogiatzis I, Holland AE, et al. An official american thoracic society/european respiratory society policy statement: Enhancing implementation, use, and delivery of pulmonary rehabilitation. Am J Resp Crit Care Med 2015;192:1373-86.

5. Keating A, Lee A, Holland AE. What prevents people with chronic obstructive pulmonary disease from attending pulmonary rehabilitation? A systematic review. Chron Respir Dis 2011;8:89-99.

6. Jones SE, Green SA, Clark AL, et al. Pulmonary rehabilitation following hospitalisation for acute exacerbation of copd: Referrals, uptake and adherence. Thorax 2014;69:181-82.

7. Maltais F, Bourbeau J, Shapiro S, et al. Effects of home-based pulmonary rehabilitation in patients with chronic obstructive pulmonary disease: A randomized trial. Ann Intern Med 2008;149: 869-78.

8. Holland AE, Mahal A, Hill C,J et al. Home-based rehabilitation for copd using minimal resources: A randomised, controlled equivalence trial. Thorax 2017;72:57-65.

9. Rosenberg SR, Kalhan R, Mannino DM. Epidemiology of chronic obstructive pulmonary disease: Prevalence, morbidity, mortality, and risk factors. Semin Respir Crit Care Med 2015;36:457-69.

10. Seemungal TA, Donaldson GC, Paul EA, et al. Effect of exacerbation on quality of life in patients with chronic obstructive pulmonary disease. Am J Resp Crit Care Med 1998;157:1418-22.

11. Spencer S, Jones PW. Time course of recovery of health status following an infective exacerbation of chronic bronchitis. Thorax 2003;58:589-93.

12. Ehsan M, Khan R, Wakefield D, et al. A longitudinal study evaluating the effect of exacerbations on physical activity in patients with chronic obstructive pulmonary disease. Ann Am Thorac Soc 2013. 2013;10:559-64.

13. Seemungal TA, Hurst JR, Wedzicha JA. Exacerbation rate, health status and mortality in copd-a review of potential interventions. Int J Chron Obstruct Pulmon Dis 2009;4:203-23.

14. Seemungal TA, Donaldson GC, Bhowmik, A et al. Time course and recovery of exacerbations in patients with chronic obstructive pulmonary disease. Am J Resp Crit Care Med 2000;161:1608-13. 
15. Suissa S, Dell'Aniello S, Ernst P. Long-term natural history of chronic obstructive pulmonary disease: Severe exacerbations and mortality. Thorax 2012;67:957-63.

16. Almagro P, Calbo E, Ochoa de Echaguen, A et al. Mortality after hospitalization for copd. Chest 2002;121:1441-48.

17. Jencks SF, Williams MV, Coleman EA. Rehospitalizations among patients in the medicare fee-for-service program. N Engl J Med 2009;360:1418-28.

18. Nici L, Bontly TD, Zuwallack R, Gross N. Self-management in chronic obstructive pulmonary disease. Time for a paradigm shift? Ann Am Thorac Soc 2014;11:101-7.

19. Hurst JR, Donaldson GC, Quint JK, Goldring JJ, et al. Temporal clustering of exacerbations in chronic obstructive pulmonary disease. Am J Resp Crit Care Med 2009;179:369-74.

20. Bodenheimer T, Wagner EH, Grumbach K. Improving primary care for patients with chronic illness. JAMA 2002;288:1775-79.

21. Nici L, Lareau S, ZuWallack R. Pulmonary rehabilitation in the treatment of chronic obstructive pulmonary disease. Am Fam Physician 2010;82:655-60.

22. Ries AL, Kaplan RM, Limberg TM, Prewitt LM. Effects of pulmonary rehabilitation on physiologic and psychosocial outcomes in patients with chronic obstructive pulmonary disease. Ann Intern Med 1995;122:823-32.

23. Harrison SL, Janaudis-Ferreira T, Brooks D, et al. Self-management following an acute exacerbation of copd: A systematic review. Chest 2015;147:646-61.

24. Jordan RE, Majothi S, Heneghan NR, et al. Supported self-management for patients with moderate to severe chronic obstructive pulmonary disease (copd): An evidence synthesis and economic analysis. Health Technol Assess 2015;19:1-516.

25. Nici L, ZuWallack R, American Thoracic Society Subcommittee on Integrated Care of the CP. An official american thoracic society workshop report: The integrated care of the copd patient. Proc Am Thorac Soc 2012;9:9-18.

26. Spruit MA, Pitta F, Garvey C, et al. Differences in content and organisational aspects of pulmonary rehabilitation programmes. Eur Respir J 2014;43:1326-37.

27. Morgan M. Expanding pulmonary rehabilitation capacity. One size won't fit all. Thorax 2017;72:4-5.

28. Revitt 0, Sewell L, Morgan MD, et al. Short outpatient pulmonary rehabilitation programme reduces readmission following a hospi- talization for an exacerbation of chronic obstructive pulmonary disease. Respirology 2013;18:1063-8.

29. Wedzicha JA, Bestall JC, Garrod R, et al. Randomized controlled trial of pulmonary rehabilitation in severe chronic obstructive pulmonary disease patients, stratified with the mrc dyspnoea scale. Eur Respir J 1998;12:363-9.

30. Strijbos JH, Postma DS, van Altena R, et al. A comparison between an outpatient hospital-based pulmonary rehabilitation program and a home-care pulmonary rehabilitation program in patients with copd. A follow-up of 18 months. Chest 1996;109: 366-72.

31. Hernandez MT, Rubio TM, Ruiz F0, et al. Results of a home-based training program for patients with copd. Chest 2000;118:106-14.

32. Behnke M, Taube C, Kirsten D et al. Home-based exercise is capable of preserving hospital-based improvements in severe chronic obstructive pulmonary disease. Respir Med 2000;94:1184-91.

33. Boxall AM, Barclay L, Sayers A, Caplan GA. Managing chronic obstructive pulmonary disease in the community. A randomized controlled trial of home-based pulmonary rehabilitation for elderly housebound patients. J Cardiopulm Rehabil 2005;25:378-85.

34. Murphy N, Bell C, Costello RW. Extending a home from hospital care programme for copd exacerbations to include pulmonary rehabilitation. Respir Med 2005;99:1297-302.

35. Regiane Resqueti V, Gorostiza A, Galdiz JB, et al. Benefits of a home-based pulmonary rehabilitation program for patients with severe chronic obstructive pulmonary disease. Arch Bronconeumol 2007;43:599-604.

36. Fernandez AM, Pascual J, Ferrando C, et al. Home-based pulmonary rehabilitation in very severe copd: Is it safe and useful? J Cardiopulm Rehabil Prev 2009;29:325-31.

37. Ghanem M, Elaal EA, Mehany M, Tolba K. Home-based pulmonary rehabilitation program: Effect on exercise tolerance and quality of life in chronic obstructive pulmonary disease patients. Ann Thorac Med 2010;5:18-25.

38. Ko FW, Cheung NK, Rainer TH, Lum C, et al. Comprehensive care programme for patients with chronic obstructive pulmonary disease: A randomised controlled trial. Thorax 2017;72:122-8.

39. Liu XL, Tan JY, Wang T, Zhang Q, et al. Effectiveness of home-based pulmonary rehabilitation for patients with chronic obstructive pulmonary disease: A meta-analysis of randomized controlled trials. Rehabil Nurs 2014;39:36-59. 